\title{
Modulation of a Neural Network by Physiological Levels of Oxygen in Lobster Stomatogastric Ganglion
}

\author{
Jean-Charles Massabuau and Pierre Meyrand \\ Laboratoire de Neurobiologie et Physiologie Comparées, Université de Bordeaux I et Centre National de la Recherche \\ Scientifique, Place du Dr Bertrand Peyneau, 33120, Arcachon, France
}

Although a large body of literature has been devoted to the role of $\mathrm{O}_{2}$ in the CNS, how neural networks function during longterm exposures to low but physiological $\mathrm{O}_{2}$ partial pressure $\left(\mathrm{PO}_{2}\right)$ has never been studied. We addressed this issue in crustaceans, where arterial blood $\mathrm{PO}_{2}$ is set in the 1-3 kPa range, a level that is similar to the most frequently measured tissue $\mathrm{PO}_{2}$ in the vertebrate CNS. We demonstrate that over its physiological range, $\mathrm{O}_{2}$ can reversibly modify the activity of the pyloric network in the lobster Homarus gammarus. This network is composed of 12 identified neurons that spontaneously generate a triphasic rhythmic motor output in vitro as well as in vivo. When $\mathrm{Po}_{2}$ decreased from 20 to $1 \mathrm{kPa}$, the pyloric cycle period increased by $30-40 \%$, and the neuronal pattern was modified. These effects were all dose- and state-dependent. Specifically, we found that the single lateral pyloric (LP) neuron

In the vertebrate brain, $\mathrm{O}_{2}$ partial pressure $\left(\mathrm{PO}_{2}\right)$ in vivo remains mainly in a low and narrow range between 1 and $3 \mathrm{kPa}$ (Lubbers, 1968; Siesjo, 1978), whereas numerous metabolic processes and enzyme reactions exhibit a $K_{\mathrm{m}}$ that is higher than the corresponding mean $\mathrm{O}_{2}$ concentrations (Jones et al., 1985; Connett et al., 1990; Vanderkooi et al., 1991). When studied in vitro, however, CNS tissue is superfused with salines equilibrated with air $\left(\mathrm{PO}_{2} \approx\right.$ $21 \mathrm{kPa})$, carbogen $\left(\mathrm{PO}_{2}=95 \mathrm{kPa}\right)$, or a $\mathrm{N}_{2} / \mathrm{CO}_{2}$ mixture $\left(\mathrm{PO}_{2}=\right.$ $0 \mathrm{kPa}$ ). For reference, $1 \mathrm{kPa}=7.5 \mathrm{~mm} \mathrm{Hg}$ or torr; in a saline solution, $1 \mathrm{kPa}$ corresponds to an $\mathrm{O}_{2}$ fraction of $\approx 1 \%$. This raises the question as to how neural networks operate at low but physiolugical $\mathrm{Po}_{2}$.

In vertebrates, no information is available regarding how changes in physiological $\mathrm{O}_{2}$ levels influence network activity. Furthermore, such studies have the added problems resulting from artificial perfusion, including altered $\mathrm{O}_{2}$ and glucose supply and clearance of metabolic end products. When these animals are studied in vivo, tissues are usually perfused. In vitro, however, which is more amenable to a cellular analysis of network activity, these tissues can only be superfused, which circumvents the normal circulatory pathways. In contrast, insights regarding the influence of $\mathrm{O}_{2}$ levels can be gained from cellular studies using the crustacean stomatogastric nervous system (STNS). This system includes the pyloric neural circuit, which constitutes one of the best understood neural networks (Harris-Warrick et al., 1992). This network is composed of 12 identified neurons that sponta-

\footnotetext{
Received Jan. 29, 1996; revised April 1, 1996; accepted April 3, 1996.

We thank John Simmers, Jorge P. Golowasch, and Michael P. Nusbaum for helpful discussions. Michael P. Nusbaum corrected the final English manuscript.

Correspondence should be addressed to J.-C. Massabuau at the above address.

Copyright $\odot 1996$ Socicty for Neuroscience $0270-6474 / 96 / 163950-10 \$ 05.00 / 0$
}

was responsible for the $\mathrm{O}_{2}$-mediated changes. At low $\mathrm{PO}_{2}$, the $L P$ burst duration increased without change in its intraburst firing frequency. Because LP inhibits the pyloric pacemaker neurons, the increased LP burst duration delayed the onset of each rhythmic pacemaker burst, thereby reducing significantly the cycling frequency. When we deleted LP, the network was no longer $\mathrm{O}_{2}$-sensitive.

In conclusion, we propose that (1) $\mathrm{O}_{2}$ has specific neuromodulator-like actions in the CNS and that (2) the physiological role of this reduction of activity and energy expenditure could be a key adaptation for tolerating low but physiological $\mathrm{PO}_{2}$ in sensitive neural networks.

Key words: respiration; oxygen; hypoxia; neural network; stomatogastric nervous system; crustaceans

neously generate a rhythmic motor pattern both in vivo and in vitro. It is located in the stomatogastric ganglion (STG), which in situ resides in the lumen of an artery where $\mathrm{PO}_{2}$ remains primarily in the 1-3 kPa range (Forgue et al., 1992b; Fig. 1B), i.e., just above $\mathrm{PO}_{2}$ at the anaerobic threshold in crustaceans (Forgue et al., 1992a). A unique feature, at least in the European lobster Homarus gammarus, is that the STG is simply bathed in arterial blood without any microcirculation. This removes the need for artificial perfusion during in vitro experiments and allows us to study neural network operation at low but physiological $\mathrm{PO}_{2}$ by simply superfusing the STG in artificial glass vessels. A second fundamental point, which eliminates the problem of an adequate continuous supply of glucose by perfusion, is the existence of exceptionally large glycogen stores in crustacean nervous tissue. The crustacean nervous system contains $\sim 80 \mu \mathrm{mol}$ of glycogen per gram of tissue, in contrast to only $2 \mu \mathrm{mol} \cdot \mathrm{gm}^{-1}$ in the mouse brain (Treherne, 1966; Wegener, 1981).

We demonstrate here that over its low but physiological range, $\mathrm{O}_{2}$ can influence neural network activity in a manner equivalent to that of a neuromodulatory transmitter. Rather than having global effects, changes in $\mathrm{O}_{2}$ levels selectively influenced the network output via a single pyloric network neuron, the LP neuron. Specifically, at low $\mathrm{PO}_{2}$, the duration of the rhythmic LP burst increased, thereby delaying each subsequent burst of the pyloric pacemaker neurons and significantly reducing the cycling activity of the pyloric network.

\section{MATERIALS AND METHODS}

All experiments were performed on the European lobster $H$. gammarus, weighing between 300 and $700 \mathrm{gm}(n=46)$, in the intermolt stage. Lobsters were obtained from local suppliers and acclimated in the laboratory for at least 1 week. They were maintained in aerated seawater 
A

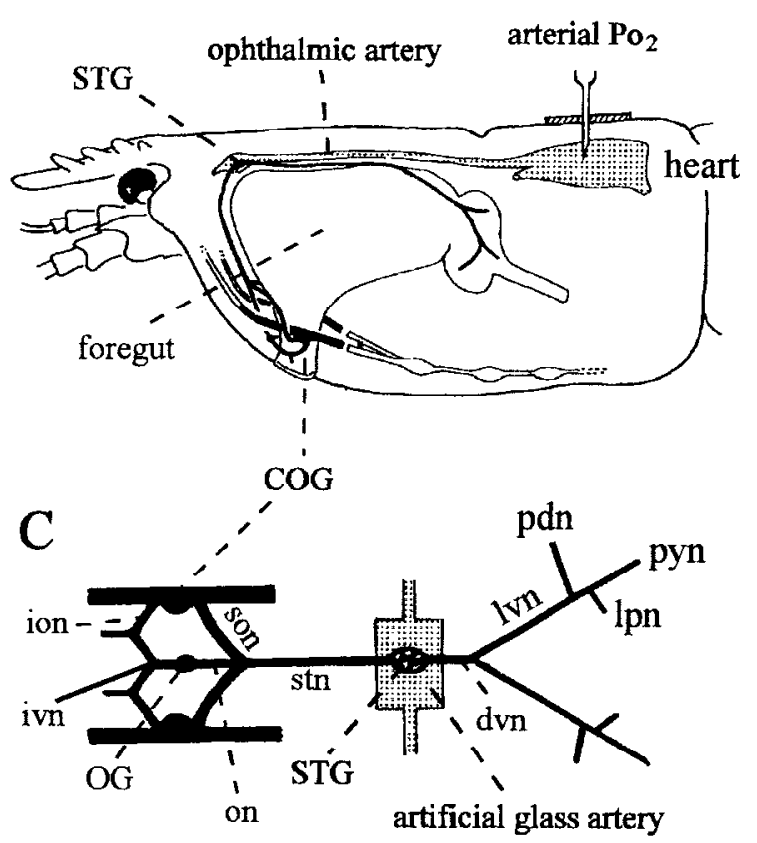

B

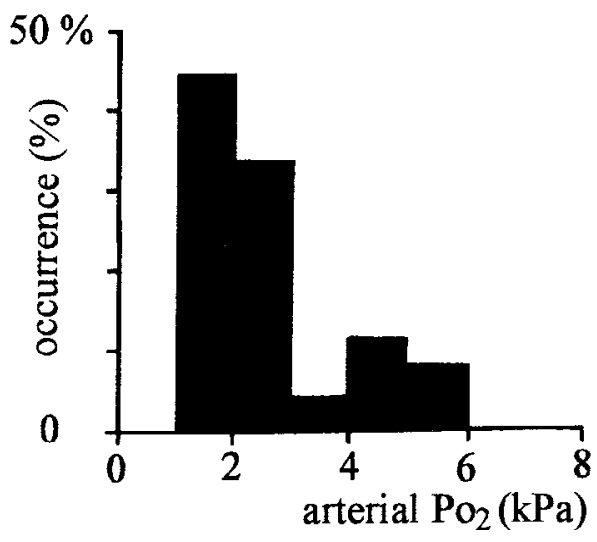

D

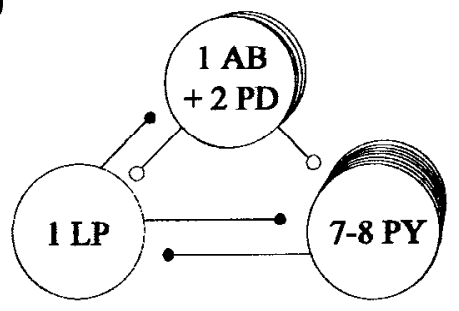

Figure 1. Experimental preparation. $A$, Lateral (left) view of the anterior region of a lobster showing the positions of the foregut, the STNS, the heart, and the ophthalmic artery, where the stomatogastric ganglion $(S T G)$ is located. A needle is shown inserted into the heart to illustrate how arterial $\mathrm{PO}_{2}$ can be measured by heart puncture and where India ink was injected. $B$. Frequency distribution of arterial $\mathrm{O}_{2}$ partial pressure $\left(\right.$ arterial $\mathrm{PO}_{2}$ ) in 27 resting and unfed $\mathrm{H}$. gammarus lobsters. The most frequently measured arterial $\mathrm{PO}_{2}$ was $1-3 \mathrm{kPa}$, with a mode of $1-2 \mathrm{kPa}$. Composite figure from Forgue et al., 1992b, plus unpublished data. $C$, Diagram of the in vitro STNS. The gray box represents the glass box used as an artificial artery. The STG, pinned on a small piece of Sylgard, was placed in this box and superfused with saline equilibrated at various $\mathrm{PO}_{2}$ levels while the remainder of the system was superfused with a standard aerated saline $\left(\mathrm{PO}_{2}=20 \mathrm{kPa},\left[\mathrm{O}_{2}\right]=250 \mu \mathrm{M}\right) . D$, The pyloric wiring diagram showing the pyloric neurons and their synaptic interactions. Open symbols represent cholinergic inhibitory synapses; closed symbols represent glutamatergic inhibitory synapses. $A B$, anterior burster neuron; $C O G$, commissural ganglion; $d v n$, dorsal ventricular nerve; ion, inferior esophageal nerve; $i v n$, inferior ventricular nerve; $L P$, lateral pyloric constrictor neuron; $l p n$, LP nerve; $l v n$, lateral ventricular nerve; $O G$, esophageal ganglion; on, esophageal nerve; $P D$, pyloric dilatator neuron; $p d n$, PD nerve; $P Y$, pyloric constrictor neuron; pyn, PY nerve; son, superior esophageal nerve; $S T G$, stomatogastric ganglion, stn, stomatogastric nerve.

tanks (salinity $=30-32 \% 0$ ) at temperatures ranging from $8-14^{\circ} \mathrm{C}$ and fed weekly with fish meat. Lobsters were anesthetized by chilling in ice for $30-45$ min before dissection.

Vascular anatomy. Experiments were performed on five animals. The STNS consists of four interconnected ganglia, including the STG (contains $\sim 30$ neurons), two commissural ganglia (CoGs) (containing $\sim 500$ neurons each), and the esophageal ganglion (OG) (contains $\sim 15$ neurons). The microcirculation in the STNS ganglia was traced by $1 \mathrm{ml}$ injections of India ink into the heart (Fig. 11). Using this technique, the black-labeled arterial blood first reaches the STG, which is located in the lumen of the ophthalmic artery at a distance of $3-5 \mathrm{~cm}$ from the heart of a 300-500 gm lobster. The arterial blood then flows to the CuGs and OG via secondary arteries. Five minutes after injection of ink, the anterior part of the STNS was dissected according to standard dissection procedures (Selverston and Moulins, 1987). The dissected STNS tissue was then cleared in methyl salicylate to reveal the finely stained microvascularization plexus. Such preparations were observed using light microscopy.

Electrophysiology. Experiments were performed on 41 preparations. The complete STNS was dissected and isolated from the foregut (Fig. 1C). The STG, CoGs, and commissural connectives were desheathed to allow access in the STG for intracellular recordings and to allow a better oxygenation in the CoGs. In terms of $\mathrm{O}_{2}$ supply, desheathing the STG corresponds to eliminating a diffusion barrier. In H. gammarus, the sheath thickness is 3-5 $\mu \mathrm{m}$ (Cournil et al., 1990). Consequently, there should be improved intracellular oxygenation in both STG and CoGs, and the main experimental bias could be that all reported observations might occur in vivo at slightly higher blood $\mathrm{PO}_{2}$. When required, selected neurons were deleted from the network by photoinactivation (Miller and Selverston, 1979). In short, this involves filling a neuron iontophoretically with Lucifer yellow dye and then illuminating the ganglion at $450-490 \mathrm{~nm}$ until the membrane potential reaches $0 \mathrm{mV}$ and activity vanishes on the corresponding nerve.
'The S"I'NS' was pinned down in a Sylgard-lined petri dish by small pins inserted through the cut ends of various nerve roots. The STG was pinned onto a separate Sylgard plate $(10 \times 6 \times 2 \mathrm{~mm})$ and enclosed in a $300 \mu \mathrm{l}$ glass chamber (internal size, $10 \times 6 \times 5 \mathrm{~mm}$ ). The chamber was supplied via gravity with saline at constant flow $\left(3-4 \mathrm{ml} \cdot \mathrm{min}^{-1}\right)$, and three holes in the upper part of the chamber (inner diameter, 1.1-1.2 $\mathrm{mm}$ each) allowed access for simultaneous intracellular recordings from the somata of three identified neurons with standard glass micropipettes filled with 3 $\mathrm{M} \mathrm{KCl}$ (resistance, $1020 \mathrm{MW}$ ). World Precision Instruments amplifiers were used for intracellular recordings and current injections. Extracellular activity was monitored with monopolar platinum electrodes and laboratory-constructed extracellular amplifiers. Signals were displayed on a Tektronix 5113 oscilloscope, stored on videotape coupled to a NeuroCorder DR 890, and recorded directly with a Gould ES 1000 electrostatic chart recorder.

Physiological saline used for STNS superfusion included $\mathrm{NaCl}, 479$ $\mathrm{mm} ; \mathrm{KCl}, 13.2 \mathrm{~mm} ; \mathrm{CaCl}_{2}, 13.7 \mathrm{~mm} ; \mathrm{MgSO}_{4}, 10 \mathrm{~mm} ; \mathrm{Na}_{2} \mathrm{SO}_{4}, 3.9 \mathrm{~mm}$ HEPES, $5 \mathrm{~mm}$. The $\mathrm{pH}$ was adjusted to 7.45 with $\mathrm{HCl}$. The entire preparation was superfused continuously with saline held at a constant temperature of $14.0+0.2^{\circ} \mathrm{C}$ by means of a laboratory-constructed thermoelectric device.

Gas mixtures. The $\mathrm{N}_{2} / \mathrm{O}_{2} / \mathrm{CO}_{2}$ gas mixture was obtained via mass flow controllers (Tylan General, model FC-260) driven by a laboratoryconstructed programmable control unit. During experiments, $\mathrm{PO}_{2}$ was varied in the $1-20 \mathrm{kPa}$ range. The $\mathrm{CO}_{2}$ partial pressure $\left(\mathrm{PCO}_{2}\right)$ was maintained at $0.4 \mathrm{kPa}$, a value typical of blood $\mathrm{PCO}_{2}$ in water-breathing animals (Rahn, 1966). The gas mixtures bubbled through the reservoir of saline feeding the STG. Between experiments, the gas-phase composition was analyzed using a paramagnetic $\mathrm{O}_{2}$ analyzer (Servomex 1100A) and an infrared $\mathrm{CO}_{2}$ analyzer (Servomex $1410 \mathrm{~B}$ ) calibrated with high grade $\mathrm{N}_{2}$ and precision gas mixtures $\left(\mathrm{Fo}_{2}=3.99 \pm 0.04 \% ; \mathrm{FcO}_{2}=1.01 \pm 0.01 \%\right)$. In the STG chamber, the absolute $\mathrm{PO}_{2}$ value was also measured periodically at the ganglion level by sampling saline through a system consisting 
Figure 2. Microcirculation in the STNS including the $(A)$ left $\mathrm{CoG}(C O G),(B)$ OG, and $(C)$ STG. The arterial microcirculation is visualized with India ink. The CoG is desheathed, whereas the OG and STG are ensheathed (tissues clarified with methyl salicylate). Notice the rich vascularization in the CoG, a few microvessels in the OG, and no microvessels in the STG. STG ncuron somata are visible on the left in C. Same symbols and abbreviations as defined in legend to Figure 1. Scale bar, $200 \mu \mathrm{m}$.
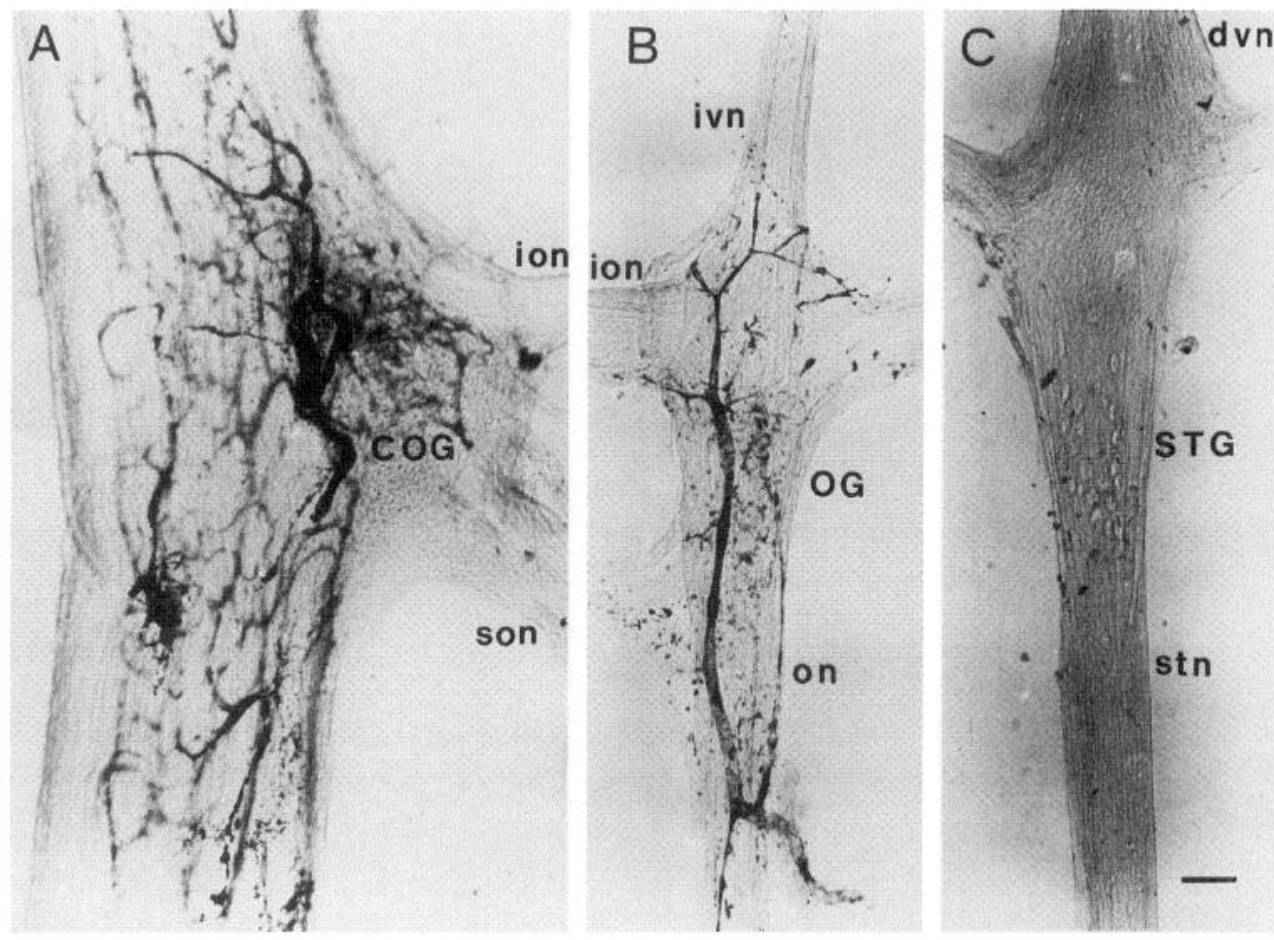

of a broken-tipped glass micropipette, an $\mathrm{O}_{2}$ polarographic electrode (Radiometer, type $\mathrm{E} 5046$ ) set at $14^{\circ} \mathrm{C}$, and a Gilson pump placed in serial order. After a change of gas composition in the bottle supplying the STG chamber, $95 \%$ of the $\mathrm{PO}_{2}$ value in the STG was changed in $<3-4 \mathrm{~min}$. At the lowest $\mathrm{PO}_{2}$ levels, the actual value was $\pm 0.1 \mathrm{kPa}$ of the nominal value. The $\mathrm{O}_{2}$ concentration in the saline was calculated according to Henry's law $\left(\mathrm{Co}_{2}=\alpha \mathrm{O}_{2} \cdot \mathrm{PO}_{2}\right)$ with $\alpha \mathrm{O}_{2}=12.4 \mu \mathrm{mol} \cdot \mathrm{L}^{-1} \cdot \mathrm{kPa}^{-1}$ at $14^{\circ} \mathrm{C}$.

Data are reported as means $\pm 1 \mathrm{SE}$, except where stated otherwise. Differences were evaluated using the paired Student's $t$-test, and $p<0.01$ was taken as the fiducial limit of significance.

\section{RESULTS}

\section{The STNS in $\boldsymbol{H}$. gammarus}

The STNS of decapod crustaceans generates the motor pattern that drives the rhythmic activity of the striated muscles that produce the movements of the foregut (Fig. 1A; also see Maynard and Dando, 1974). In vitro, the STNS of $H$. gammarus produces three motor outputs spontaneously and continuously. These motor programs are generated by three discrete neural networks (Meyrand et al., 1994). Among them, the pyloric network presents the most active rhythm with the highest bursting frequency. It is composed of 12 neurons, all located in the STG, which are responsible for the peristaltic-like dilation and constriction of the pyloric chamber. Their rhythmic output is a triphasic recurrent activity involving the sequential activation of pyloric dilator (PD), anterior constrictor (LP), and posterior constrictor (PY) motoneurons. The in vitro pyloric rhythm is similar to the rhythm expressed in vivo (Rezer and Moulins, 1983). This rhythmic motor pattern has been studied extensively during the past 20 years (Miller, 1987; Harris-Warrick et al., 1992), and a wiring diagram has been developed that results from experiments that combine electrophysiological, pharmacological, and single neuron photoinactivation techniques (Miller and Selverston, 1979; Cazalets et al., 1990b). The three functional subsets of neurons that compose the pyloric network are illustrated in Figure $1 D$. The dilator group consists of two PD neurons and one pyloric interneuron, the anterior burster neuron. These three neurons are strongly electrically coupled and consequently exhibit synchronous activity.
They express endogenous oscillatory properties and are considered the pacemaker unit of this network (Cazalets et al., 1987; Miller, 1987). They rhythmically inhibit the constrictor neurons, which consist of two subsets. The first one is composed of the single LP constrictor neuron, and the second one consists of seven to eight electrically coupled pyloric (PY) constrictor neurons. Although the two sets of constrictor neurons make reciprocal inhibitory connections, the LP neuron is the only cell in the pyloric network that makes an inhibitory synapse onto the pacemaker group (Fig. 1D). Consequently, within the pyloric network, LP is the only neuron able to modify directly the rhythmic activity of the pacemaker group.

All neurons of the pyloric network express intrinsic oscillatory and/or plateau properties (Cazalets et al., 1990b), which play a critical role in the expression of the network activity (Bal et al., 1988). Moreover, these properties as well as the synaptic properties are under the control of descending modulatory inputs from the CoG and the OG (Nagy et al., 1988; Cazalets et al., 1990a; Cournil et al., 1990; Meyrand et al., 1991).

\section{Vascular anatomy of the STNS in $\boldsymbol{H}$. gammarus}

One of the major problems in studying $\mathrm{O}_{2}$ supply mechanisms in the in vitro $\mathrm{CNS}$ is the presence of the microcirculation. Although King (1976) reported the presence of small blood vessels within the STG neuropil of the spiny lobster Panulirus interruptus, Moulins and coworkers (unpublished data) never observed such vessels in the H. gammarus STG, at either the light or the ultrastructural level. We reexamined this issue in $H$. gammarus by using India ink as a tracer. After ink injections into the heart, we observed no microvascularization in the ensheathed STG, in contrast to the vessels revealed in the desheathed $\mathrm{CoG}$ and ensheathed OG (Fig. 2). The dye reliably stained $(n=5)$ a complex and rich vascularized system in both CoGs (Fig. $2 A$ ) and OG (Fig. $2 B$ ), but we never observed stained vessels in the STG (Fig. 2C). Thus, in situ the STG is simply bathed in the arterial blood, which has a $\mathrm{Po}_{2}$ mainly in the $1-3 \mathrm{kPa}$ range (Fig. $1 B$ ). This unique 


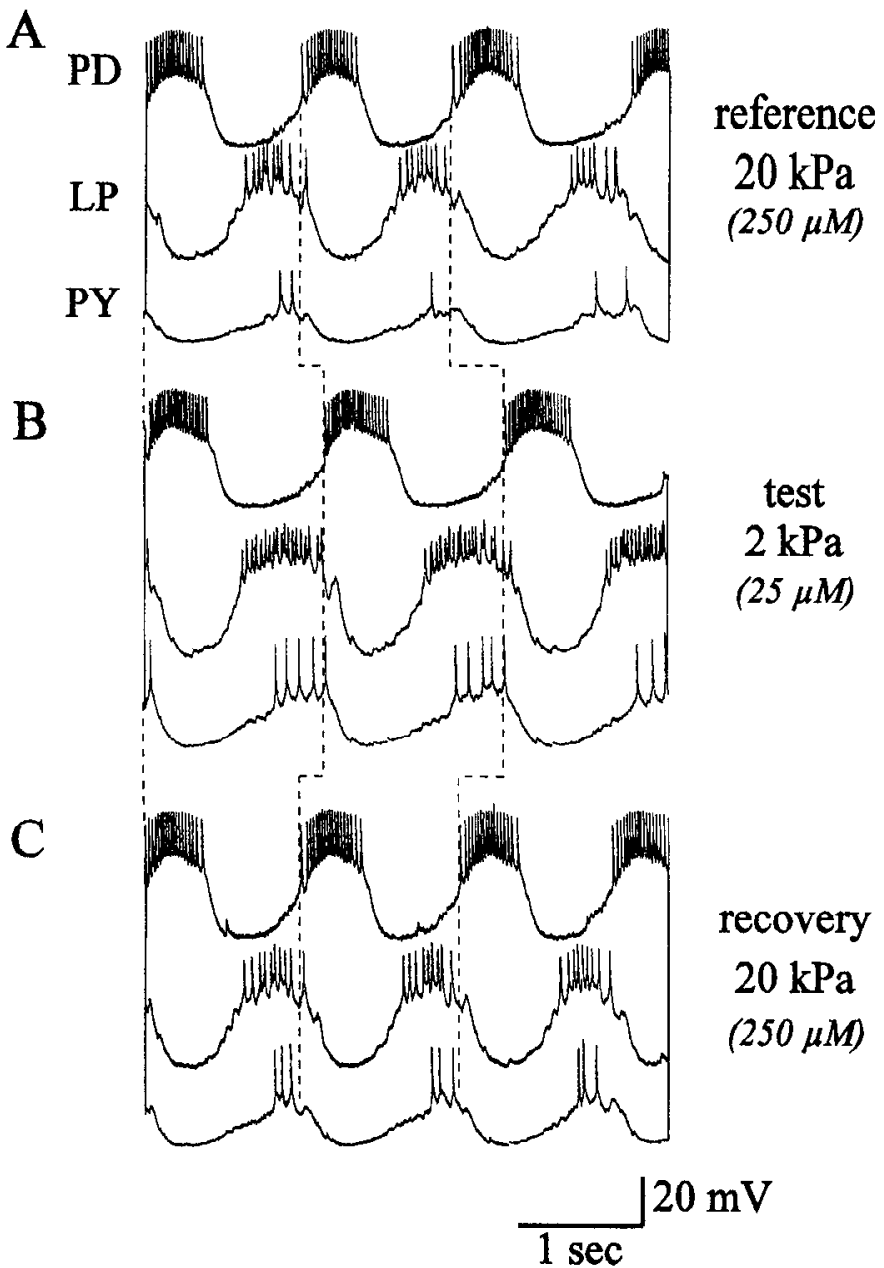

Figure 3. Effect of low but physiological $\mathrm{PO}_{2}$ on the pyloric rhythm. The pyloric rhythm is monitored by simultaneous intracellular recordings from one pacemaker neuron $(P D)$ plus the constrictor neurons $L P$ and $P Y . A$, Spontaneous pyloric rhythm at $\mathrm{PO}_{2}=20 \mathrm{kPa}$. $B$, At the low end of the physiological $\mathrm{PO}_{2}$ range $\left(\mathrm{PO}_{2}=2 \mathrm{kPa}\right)$, LP burst duration increases. This delays the onset of each subsequent burst in the pyloric pacemaker neurons and increases the pyloric cycle period. $C$, recovery at $\mathrm{PO}_{2}=20$ $\mathrm{kPa}$. Pyloric rhythms were recorded after $60 \mathrm{~min}$ superfusion with each solution. The $\mathrm{O}_{2}$ concentrations that correspond to each applied $\mathrm{PO}_{2}$ are shown in parentheses.

anatomical feature removes the need for artificial perfusion. It allowed us to study the functioning of the pyloric network by performing in vitro experiments in which the STG was superfused via artificial glass arteries that closely mimicked the in vivo situation. Because of their rich vascularization, however, the in vitro situation for the CoGs and OG was very different from in vivo. Consequently, to preserve the activity of the modulatory inputs to the STG, these ganglia were always superfused with aerated saline at $\mathrm{PO}_{2}=20 \mathrm{kPa}$ and $\mathrm{PCO}_{2}=0.4 \mathrm{kPa}$.

\section{Effects of physiological $\mathrm{PO}_{2}$ on the pyloric rhythm}

When the STG was superfused with a reference aerated saline (i.e., $\mathrm{PO}_{2}=20 \mathrm{kPa}$ corresponding to an $\mathrm{O}_{2}$ concentration of 250 $\mu \mathrm{M})$, the pyloric network generated its rhythmic triphasic output, and the pyloric neurons showed their well described bursting activity (Fig. $3 \mathrm{~A}$ ). Decreasing $\mathrm{PO}_{2}$ toward low blood physiological values shown in Figure $1 B$ (for example $\mathrm{PO}_{2}=2 \mathrm{kPa}, \mathrm{O}_{2}$ concentration $25 \mu \mathrm{M}$ ) modified the pyloric output (Fig. 3B). By compar- ison with the reference situation (Fig. 3A), two striking and reliable changes were observed. These included an increased pyloric cycle period and dramatic increases in LP and PY burst durations. Surprisingly, all pyloric neuron membrane potentials remained unchanged. Note that after such exposures (up to $6 \mathrm{hr}$ in some experiments), these modifications were reversible (Fig. $3 C)$. The action of $\mathrm{PO}_{2}=1 \mathrm{kPa}\left(\mathrm{O}_{2}\right.$ concentration $\left.12.5 \mu \mathrm{m}\right)$ on the pyloric cycle period is shown in Figure $4 A$, in comparison with the reference situation at $\mathrm{PO}_{2}=20 \mathrm{kPa}$. At $1 \mathrm{kPa}$, pyloric activity was characterized by a mean cycle period $>1.2 \mathrm{sec}(n=294 / 296$ in 11 different experiments). In contrast, most of the cycle periods occurring at $\mathrm{PO}_{2}=20 \mathrm{kPa}$ were briefer than $1.2 \mathrm{sec}(n=238 / 330$ in 11 experiments). This shows that in our experimental conditions, $\mathrm{PO}_{2}=1 \mathrm{kPa}$ prevented the expression of pyloric cycle periods shorter than $1.2 \mathrm{sec}$. In addition to this global analysis, it must be noted that the percentage by which the pyloric cycle period increased was variable among experiments $(32 \pm 23 \%$, mean $\pm \mathrm{SD}$ ). This nonhomogeneous result recalls previously describcd actions of ncuromodulators on the pyloric network. Indeed, it has been shown that the actions of neuromodulators depend on the previous physiological state in the STG (Hooper and Marder, 1987; Nusbaum and Marder, 1989; Turrigiano and Selverston, 1989). Figure $4 B$ shows that the low $\mathrm{PO}_{2}$ effect was also state-dependent. Thus, the effect was minor or null in preparations exhibiting slow pyloric rhythms at $20 \mathrm{kPa}(\mathrm{T}>1.4 \mathrm{sec})$ but dramatic in the most active preparations. Figure $4 C$ shows that in addition to this state-dependency, the $\mathrm{O}_{2}$ effect was also dosedependent. This was studied while a series of seven different $\mathrm{PO}_{2}$ plateaus was performed, which were presented in the following order: $\mathrm{PO}_{2}=20,6,4,3,2,1$, and $20 \mathrm{kPa}$. The duration of each exposure was $60 \mathrm{~min}$, with the new rhythm occurring at each $\mathrm{Po}_{2}$ attaining equilibrium within $20-30 \mathrm{~min}$. It is clear that the effect on the pyloric cycle period was linked in a dose-dependent manner to the $\mathrm{PO}_{2}$ value. The $\mathrm{PO}_{2}$ threshold was below $6 \mathrm{kPa}(75 \mu \mathrm{M})$, and the effect was maximum at the lowest tested $\mathrm{PO}_{2}=1 \mathrm{kPa}$ $\left(12.5 \mu \mathrm{M} ; p=0.01\right.$, paired $t$ tests). Note again that the $\mathrm{O}_{2}$-induced effect was reversible, because a $5 \mathrm{hr}$ exposure period at $\mathrm{PO}_{2}$ ranging from $1-6 \mathrm{kPa}$ did not lead to any statistical difference between reference (closed symbol) and recovery (open symbol) periods at $20 \mathrm{kPa}$ (paired $t$ tests).

Finally, in addition to the state- and dose-dependent effects of $\mathrm{O}_{2}$ on the pyloric cycle frequency, $\mathrm{O}_{2}$ also influenced the pattern of the pyloric rhythm. The change that occurred in the relative phasing and duty cycles (i.e., the fraction of the cycle during which a neuron is active) after $1 \mathrm{hr}$ exposure periods at 20,1 , and $20 \mathrm{kPa}$ are presented in Figure 5 ( $n=8$ different preparations). At $\mathrm{Po}_{2}=$ $1 \mathrm{kPa}$, the main effect is an increase of the LP and PY duty cycles (by 50\% and $150 \%$, respectively), with an increased amount of overlap between their discharges. Additionally, PD duty cycle decreased, although it must be noted that the absolute PD neuron burst duration was statistically unchanged, whatever the $\mathrm{PO}_{2}$ (Fig. $6 B$ ). Note also that (1) the absolute mean value of the silent gap between the $\mathrm{PD}$ and $\mathrm{LP}$ discharges remained constant regardless of $\mathrm{PO}_{2}(0.25 \pm 0.03 \mathrm{sec}$ at $20 \mathrm{kPa}$ and $0.24 \pm 0.09 \mathrm{sec}$ at $1 \mathrm{kPa}$, paired $t$ tests), as did (2) the mean latency between the onset of the LP and PY bursts during the reference and test periods $(0.25$ $\pm 0.09 \mathrm{sec}$ and $0.22 \pm 0.10 \mathrm{sec}$, respectively), and of course (3) the sum of both delays, which corresponds to the latency between the end of the inhibitory PD burst and the onset of the PY firing (also see Fig. 3). 
Figure 4. Characterization of the $\mathrm{O}_{2}$ effect on the pyloric network. $A$, Distribution of pyloric cycle period at $\mathrm{PO}_{2}=$ $20 \mathrm{kPa}$ and after $60 \mathrm{~min}$ at $\mathrm{PO}_{2}=1 \mathrm{kPa}$ ( $n=11$ preparations). At $\mathrm{PO}_{2}-20 \mathrm{kPa}$, $75 \%$ of the cycle periods are $<1.2 \mathrm{sec}$, whereas at $\mathrm{PO}_{2}=1 \mathrm{kPa}$, all pyloric cycle periods are $>1.2 \mathrm{sec}$. $\mathrm{O}_{2}$ concentration that corresponds to the applied $\mathrm{PO}_{2}$ is shown in parentheses. $B$, The $\mathrm{O}_{2}$ effect is state-dependent. Percentage increase in pyloric cycle period at $\mathrm{PO}_{2}=1 \mathrm{kPa}$ as a function of the reference cycle period at $20 \mathrm{kPa}$. Each data point is the mean value of $>30$ cycles from 11 preparations. $C$, The $\mathrm{O}_{2}$ effect is dose dependent and reversible in $\mathrm{O}_{2}-$ sensitive preparations. Data represent mean \pm SE. Closed circles indicate reference and test values, and open circle indicates recovery value $(n=8$ preparations).
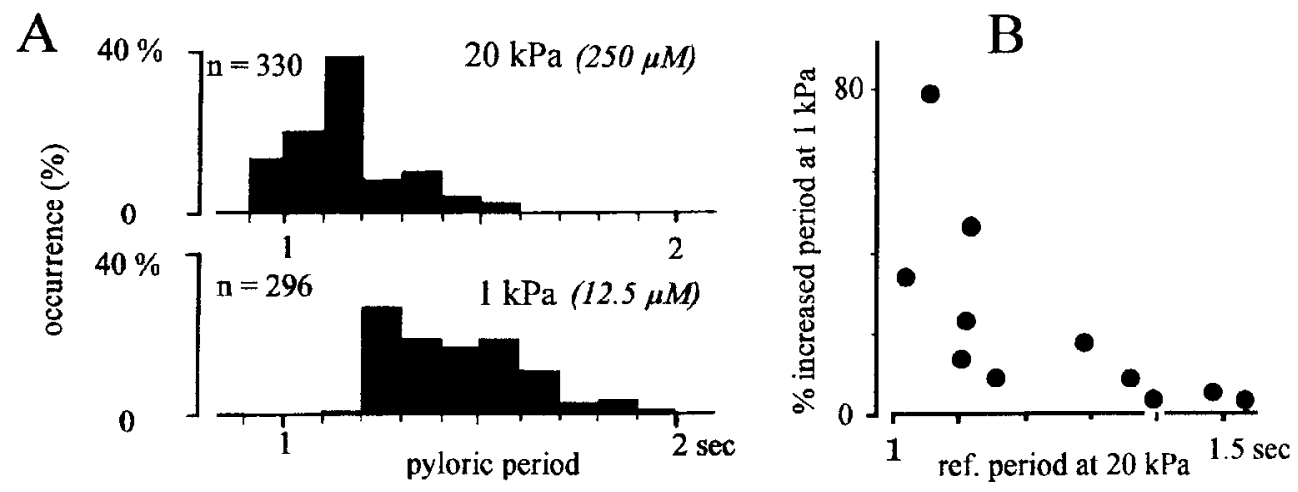

C

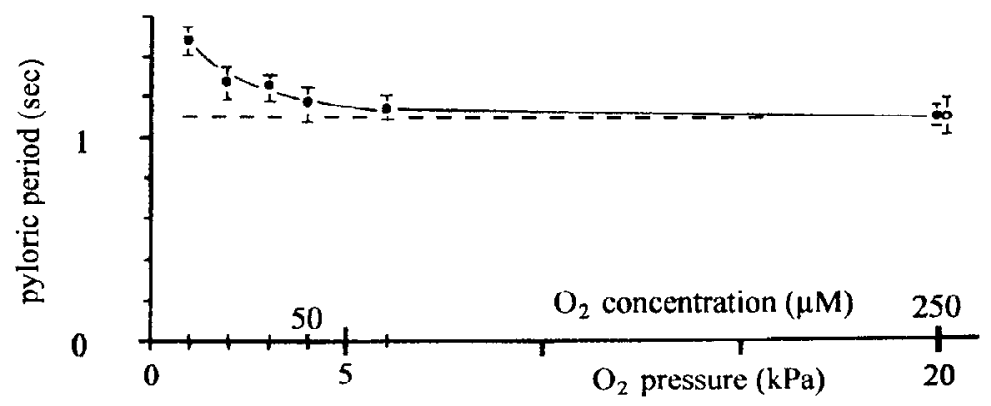

\section{Specificity of the network $\mathrm{O}_{2}$ effect via a unique neuron, the LP neuron}

The above data set showed that the pyloric cycle period increased by $\sim 30 \%$ at low physiological $\mathrm{PO}_{2}$ when compared with the standard, albeit artificial reference at $20 \mathrm{kPa}$. We next addressed the issue regarding the origin of this altered pyloric rhythm. Specifically, we examined whether the change in cycle frequency resulted from a direct $\mathrm{O}_{2}$ effect on the pacemaker group or as an indirect result of its influence on other network components. With regard to the latter possibility, it seemed more likely that a key element of the $\mathrm{O}_{2}$ actions would be the LP neuron and not the PY neurons, because only the LP neuron directly inhibits the pacemaker group and could thereby delay their firing (Fig. 1D). Consequently we focused our attention first on the LP neuron and the pacemaker group.

Figure 6 presents a burst analysis for these two cellular groups. It is evident from these data that the decreased $\mathrm{PO}_{2}$ influenced the LP burst duration considerably more than the PD burst duration (Fig. 6A-B). Specifically, between $\mathrm{PO}_{2}=20$ and $1 \mathrm{kPa}$, the LP burst duration increased significantly $(+87 \%$ : from $0.31+0.02$ sec to $0.58 \pm 0.06 \mathrm{sec} ; n=7$ preparations). In contrast, the PD burst duration did not change statistically $(0.45 \pm 0.05 \mathrm{sec}$ at 20 $\mathrm{kPa}$ and $0.49 \pm 0.03 \mathrm{sec}$ at $1 \mathrm{kPa}$ ). Interestingly, the intraburst firing frequency remained independent of $\mathrm{PO}_{2}$ in both neurons. The $\mathbf{L P}$ firing frequency was $33.5 \pm 3.4 \mathrm{~Hz}$ at $20 \mathrm{kPa}(n=9)$ and $32.0 \pm 4.5 \mathrm{~Hz}$ at $1 \mathrm{kPa}(n=7$; Fig. $6 C)$, whereas for PD at the same $\mathrm{O}_{2}$ partial pressurcs, it was $45.1 \pm 3.3 \mathrm{~Hz}(n=7)$ and 43.7 $\pm 1.7 \mathrm{~Hz}(n=5$; Fig. $6 D)$, respectively. This absence of any increase in firing frequency contrasts strongly with what is known in so-called hypoxic or asphyxic preparations. It suggests, together with the recovery pattern shown in Figures $3,4 C$, and 5 , that cellular integrity was maintained in our experimental preparations regardless of the $\mathrm{PO}_{2}$ value. Because the LP neuron seemed to be the only network neuron whose activity was both modified by $\mathrm{O}_{2}$ in the studied range and able to delay the firing of the pacemaker group, we tested its role at low $\mathrm{PO}_{2}$ by (1) manipulating its burst duration and (2) deleting it from the network.

Figure 7 presents a typical experiment in which we studied the effect on the pyloric rhythm of injecting hyperpolarizing pulses of current $(2-3 \mathrm{nA})$ in LP to shorten its burst duration at $1 \mathrm{kPa}(n=$ 3 experiments). It illustrates again that at $\mathrm{PO}_{2}=1 \mathrm{kPa}$, the pyloric cycle period increased (compare Fig. 7, $A$ and $B 1$ ), but more importantly, that under these conditions the shortening of the LP burst reversed the $\mathrm{O}_{2}$-induced slowing of the pyloric rhythm (compare Fig. 7, B1 and B2). This suggested that it was not the cyclic activity of the pacemaker group by itself that was directly responsible for the decreased cycle frequency at low $\mathrm{Po}_{2}$. Instead, the increased LP burst duration apparently inhibited the pacemaker group sufficiently well to slow its bursting activity. To confirm this LP-mediated mechanism, we experimentally deleted LP from the network by photoinactivation (see Materials and Methods). For this experimental series ( $n=4$ experiments), we used preparations with fast pyloric rhythms under control conditions, because it is in this situation that the $\mathrm{O}_{2}$ effect is strongest (Fig. 4B). It must be noted at first that after LP deletion the remaining pyloric cells still generated rhythmic activity, with an alternation between bursts in the PD and PY neurons and a constant cycle period (Fig. $8 B 1$ ). In these LP-deleted preparations, when $\mathrm{PO}_{2}$ was reduced to $1 \mathrm{kPa}$, there was no increase in the pyloric cycle period (compare Fig. 8, B1 and $B 2$ ). Even after long-term exposures to low $\mathrm{PO}_{2}(>1 \mathrm{hr})$, the LP-deleted pyloric rhythm remained unchanged. Figure $9 A$ presents a plot of the pyloric cycle periods pooled from the four experiments. Contrary to what occurred in the intact network (Fig. 4A), the LP-deleted network displayed a constant pyloric cycle period regardless of $\mathrm{PO}_{2}(1-20 \mathrm{kPa})$. This implies that the low $\mathrm{PO}_{2}$ had no direct effect on $\mathrm{AB}, \mathrm{PD}$, and $\mathrm{PY}$ activity. Moreover, although in the intact network the pattern of activity was reliably modified at $1 \mathrm{kPa}$ (Fig. 5 ), this effect disappeared when LP was deleted (Fig. 9B). Thus, 

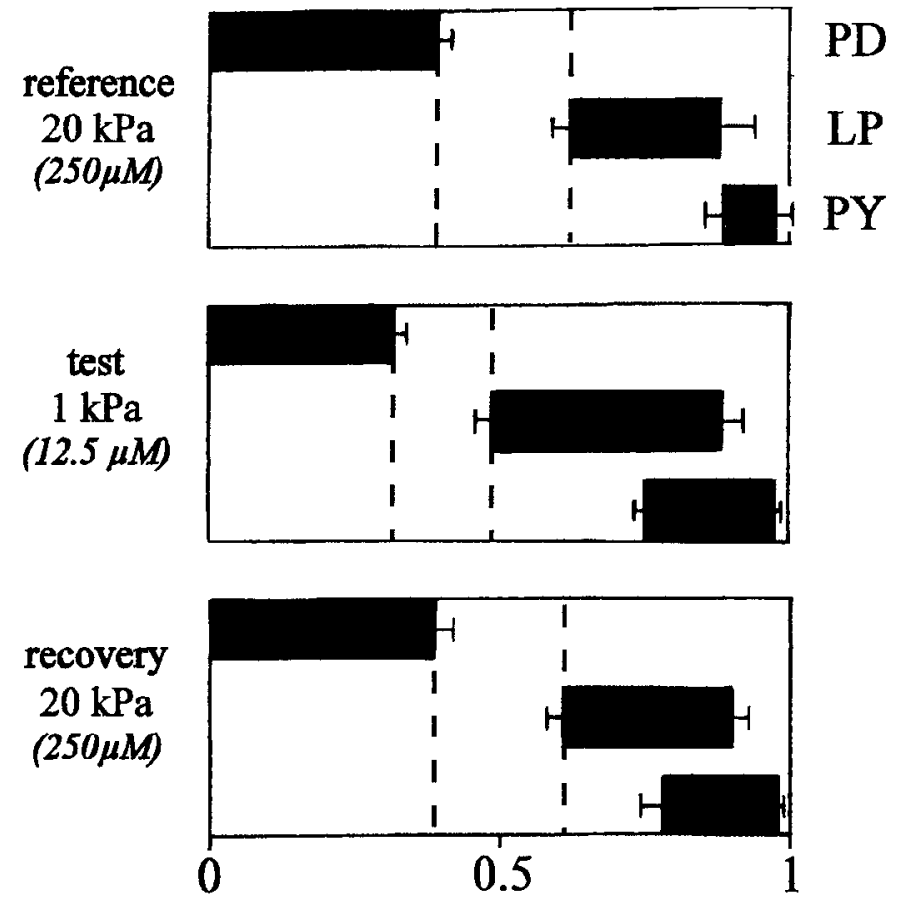

Figure 5. Normalized phase relationship of the pyloric neurons under different $\mathrm{PO}_{2}$ levels. The global pyloric activity pattern is altered in a reversible manner between $\mathrm{PO}_{2}=20 \mathrm{kPa}$ (reference) and $1 \mathrm{kPa}(t e s t)$. Bar diagram represents mean phases of the pyloric neuron bursts during one normalized cycle of the pyloric rhythm. Phase onset and phase offsct are calculated as the fraction of the cycle that has elapsed before the onset and offset, respectively, of the burst in a pyloric neuron divided by the cycle period. The onset of consecutive bursts in the PD neuron is arbitrarily designated as the beginning and end, respectively, of a pyloric cycle. Mean $\pm \mathrm{SE}(n=8$ preparations).

without the LP neuron, the pyloric network became insensitive to $\mathrm{O}_{2}$ changes in the studied range.

\section{DISCUSSION}

The present results show that changes in $\mathrm{O}_{2}$ levels over the physiological range $\left(\mathrm{PO}_{2}=1-6 \mathrm{kPa}\right.$; corresponding to $\left[\mathrm{O}_{2}\right]=$ 12.5-75 $\mu \mathrm{M}$ ) reversibly alter the output of the lobster pyloric network in a manner similar to neuromodulatory transmitters.
Our data demonstrate that (1) the pyloric rhythm remained unchanged when $\mathrm{PO}_{2}$ varied from $6-20 \mathrm{kPa}$, (2) the pyloric cycle period increased in a reversible manner by $\sim 30-40 \%$ when $\mathrm{PO}_{2}$ decreased from $6 \mathrm{kPa}$ to $1 \mathrm{kPa}$, and (3) the relative phasing and duty cycles of the three pyloric neuron subsets were altered when $\mathrm{PO}_{2}$ was decreased. These effecls were dose- and state-dependent. Among the 12 pyloric neurons, $\mathrm{O}_{2}$ acted specifically via the single LP neuron. Thus, rather than globally changing the activity of all pyloric network neurons, the $\mathrm{O}_{2}$ effect was quite similar to that reported previously for exogenously applied modulatory transmitters in the STNS (Hooper and Marder, 1987; Harris-Warrick et al., 1992).

\section{Specificity of the LP neuron in the $\mathrm{O}_{2}$ network effect}

When the STG was superfused with $\mathrm{PO}_{2}$ in the physiological range, we observed dramatic effects on both the cycle period and the pattern of the pyloric rhythm relative to the rhythm in the presence of standard, aerated saline. As discussed below, we found that the LP neuron played a key role in these effects. This conclusion comes from cxperiments performed in intact (Figs. 3-6) and LP-deleted networks (Figs. 7-9). It will be interesting to determine whether $\mathrm{PO}_{2}$ changes directly influence the I.P neuron. Synaptic interactions within the pyloric network are fairly complex, and the way in which a neuron responds to a neuroactive substance when that neuron is embedded in a network can differ from its response when isolated from that network. For example, in the STNS, dopamine and proctolin indirectly activate the PD neurons when they belong to the intact network, but dopamine inhibits and proctolin is without effect when these neurons are isolated experimentally and therefore influenced only directly (Flamm and Harris-Warrick, 1986a,b; Hooper and Marder, 1987).

Although the cellular mechanisms of $\mathrm{O}_{2}$ action on LP were outside the scope of this paper, we have presented the effects induced by decreasing $\mathrm{PO}_{2}$ on the pyloric rhythm cycle frequency and on the phasing and duty cycle of the pyloric component ncurons. We suggest that the increased pyloric cycle period is entirely an LP-mediated effect. Specifically, in the intact network at low $\mathrm{PO}_{2}$, the increased LP burst duration enhanced its synaptic inhibition of the pacemaker neurons ( $P D$ and $A B$ ), thereby delaying the onset of each subsequent burst in the pacemaker neurons and increasing the pyloric cycle period. On the contrary, at $\mathrm{PO}_{2}=20 \mathrm{kPa}$, the LP inhibition of the pacemaker neurons

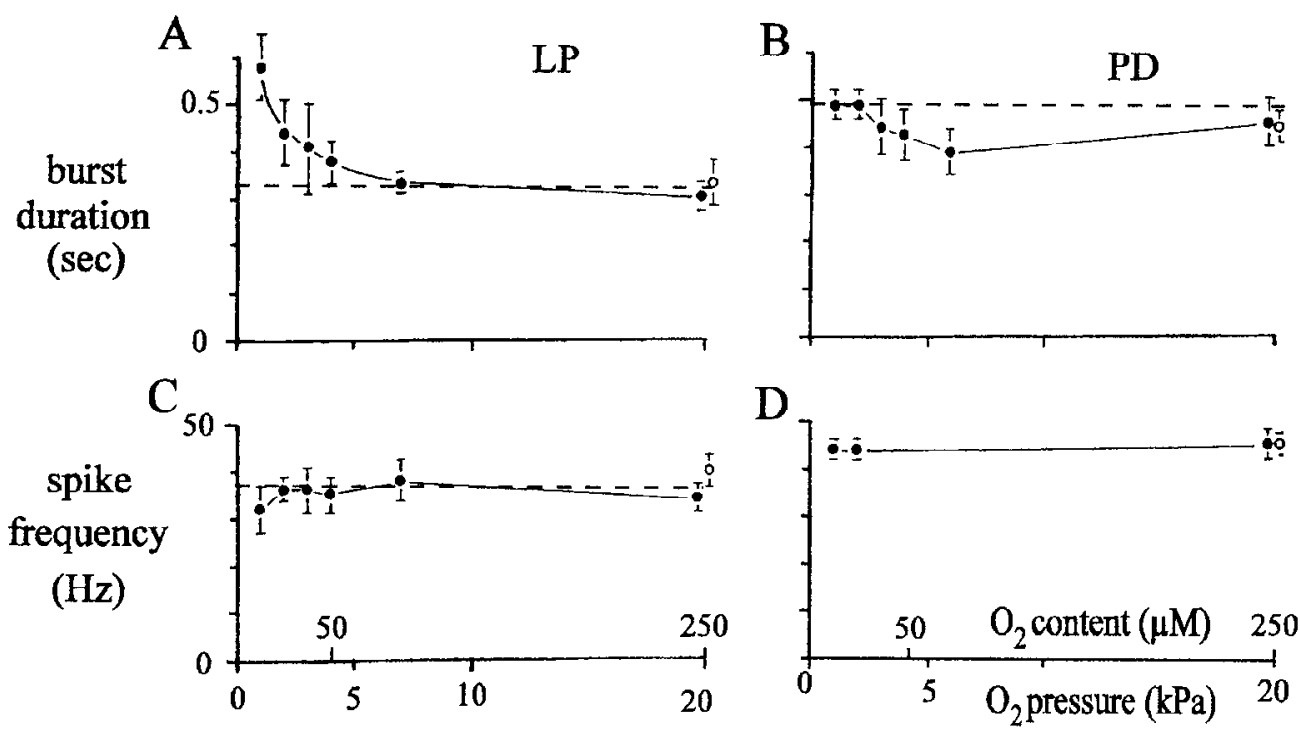

Figure 6. Low physiological $\mathrm{PO}_{2}$ levels increase, reversibly, the LP neuron burst duration $(A)$ but not the PD burst duration $(B)$. The change in $\mathrm{PU}_{2}$ does not modify the intraburst spike frequency in either $L P$ or $P D(C, D)$. Each mean value was measured at the end of a 60 min exposure period. Mean $\pm \mathrm{SE}(n=$ 7-8 preparations). Closed circles represent reference and test values, and open circle indicates recovery value. 


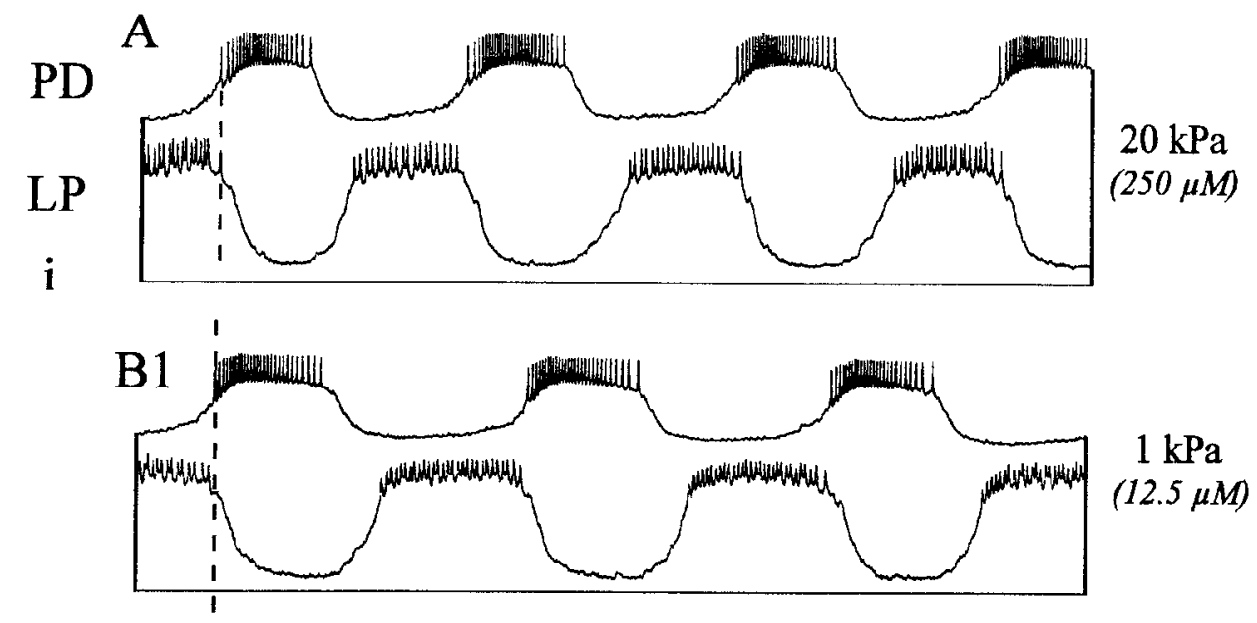

Figure 7. Reducing the duration of the LP burst via hyperpolarizing current injection at low $\mathrm{PO}_{2}$ levels restores the pyloric period toward its value at high $\mathrm{PO}_{2} . A$, Intracellular recordings of the $\mathrm{PD}$ and $\mathrm{LP}$ neurons at $\mathrm{PO}_{2}$ $=20 \mathrm{kPa}$. B1, The LP burst duration and the delay between subscquent $P D$ bursts are increased at $\mathrm{PO}_{2}=1 \mathrm{kPa} . \mathrm{B2}$, The rhythmic reduction of the $\mathrm{LP}$ burst at $\mathrm{PO}_{2}=1 \mathrm{kPa}$ by rhythmic hyperpolarizing current injection (i) reduced the pyloric period.

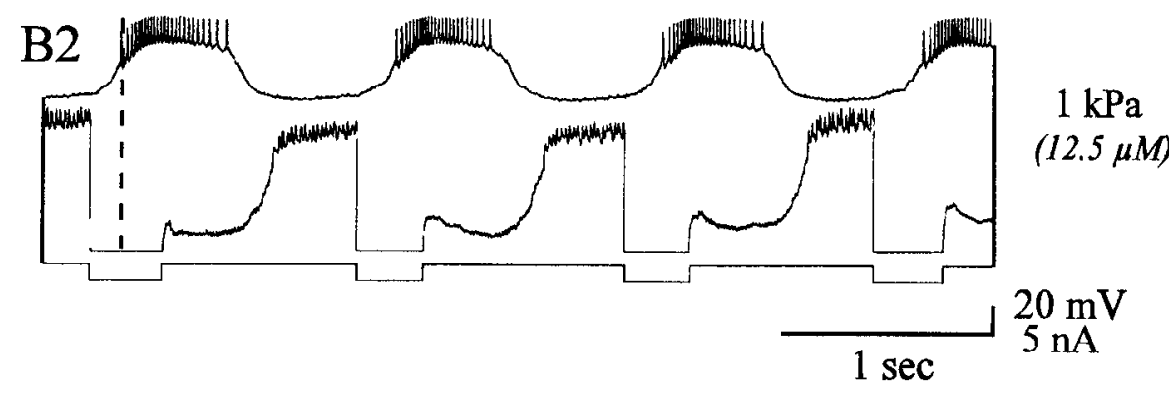

seems to have no regulatory effect on the pyloric rhythm. Indeed, when LP was deleted from the network at this high unphysiological $\mathrm{PO}_{2}$, the $\mathrm{PD}$ cycle period remained unchanged (Figs. 8A,B1, $9 A$ ). Obviously, this $\mathrm{O}_{2}$-related change in LP synaptic efficacy requires further study. Nevertheless, the present work reports the first documented modulation of the pyloric rhythm that alters the pyloric cycle period via an indirect influence on the pacemaker neurons. Previously, several sources of modulatory input have been shown to influence the pyloric cycle period via a direct effect on the pacemaker neurons (Nagy and Dickinson, 1983; Hooper and Marder, 1987; Nusbaum and Marder, 1989; Cazalets et al., 1990a,b).

It is also noteworthy that different mechanisms were responsible for the modifications of phasing and duty cycle in PD and PY, and yet their intrinsic properties were $\mathrm{O}_{2}$-insensitive, as demonstrated in the reduced network (Fig. 9A,B). Thus, the PD duty cycle decreased in the intact network at low $\mathrm{Po}_{2}$ (because the pyloric period increased and the PD burst duration was unchanged), whereas both the PY burst duration and the duty cycle increased. Any explanation for the latter effect remains speculative, but because the latency between the onset of the LP and PY neuron bursts remained constant when $\mathrm{PO}_{2}$ decreased (Fig. 5), it seems likely that the LP inhibition of the PY neurons is timedependent. Time-dependent synaptic effects are known to occur within the STG. Indeed, depolarization of a presynaptic neuron via a long-lasting plateau evokes a biphasic response in the postsynaptic neurons that includes an early transient sharp peak followed by a smaller sustained response (Graubard et al., 1983). In the present situation, we propose that when the LP burst was shortened at $\mathrm{PO}_{2}=20 \mathrm{kPa}$, only the initial transient component was expressed, and it evoked a strong and constant inhibition of the PY neurons. Conversely, at low $\mathrm{PO}_{2}$, the LP burst duration increased and allowed the activation of the second, weaker inhib- itory component. This latter component may be unable to sustain reliably the inhibition of the PY neurons, and a longer PY burst duration occurs. It must now be explained, however, how the LP neuron can fire despite the classical view that the PY neurons inhibit LP. For this, it must be kept in mind that the PY population can be divided into two subpopulations. The first one inhibits the LP neuron and has been reported to systematically fire after the LP burst. The second group does not inhibit LP (Maynard, 1972; Hardline and Gassie, 1979; Eisen and Marder, 1984). An increase in pyloric period at low $\mathrm{PO}_{2}$ could simply allow the firing of this second type of PY neuron during the second weaker part of the LP burst. In this respect, note that the time latency between the end of the inhibitory PD burst and the onset of the PY firing remains constant, whatever the $\mathrm{PO}_{2}$. This means that the inhibition by PDs of the PYs remains constant. In the present work, because the different PY neurons are difficult to identify, we treated them as a single population.

In summary, the selective alteration of LP neuron activity accounts for all of the $\mathrm{O}_{2}$ effects on the pyloric network, and an LP-deleted network becomes $\mathrm{O}_{2}$ insensitive. At physiological $\mathrm{PO}_{2}$, the LP neuron has two functional roles. It changes the phase relationships in the pyloric network, and it reduces the network activity by increasing the pyloric rhythm cycle period.

\section{Why reduce neuronal activity at low $\mathrm{Po}_{2}$ ?}

During the pyloric rhythm, the membrane potential of each neuron oscillates, generates spikes, and receives rhythmic synaptic inputs. Each of these events changes the membrane potential via a change of ionic fluxes for which there must be active compensation to maintain electrochemical gradients. Reuptake, resynthesis, and repacking of neurotransmitters also require a constant flux of energy. The physiological processes involved in this perpetual rebuilding represent an energy expenditure that is difficult 
$A$ Control at $\mathrm{Po}_{2}=20 \mathrm{kPa}(250 \mu \mathrm{M})$

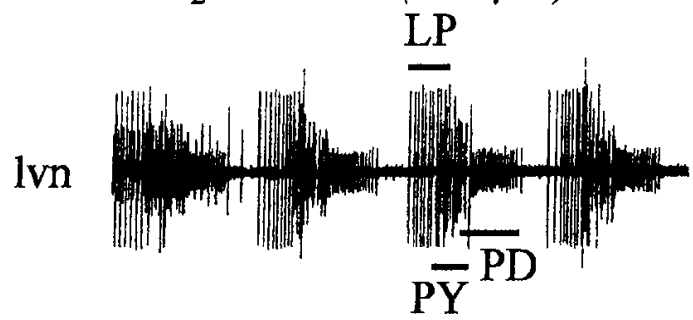

B1 LP killed at $\mathrm{Po}_{2}=20 \mathrm{kPa}(250 \mu M)$

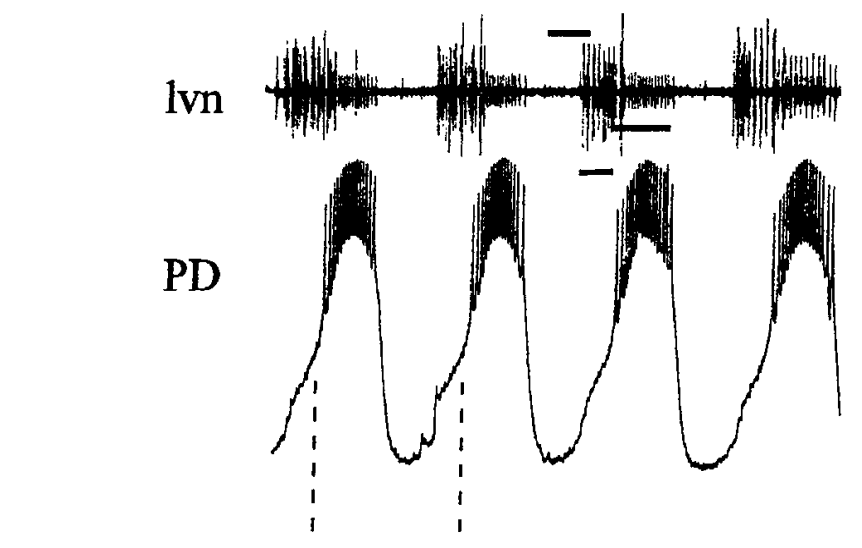

B2 LP killed at $\mathrm{Po}_{2}=1 \mathrm{kPa} \quad(12.5, \mu M)$

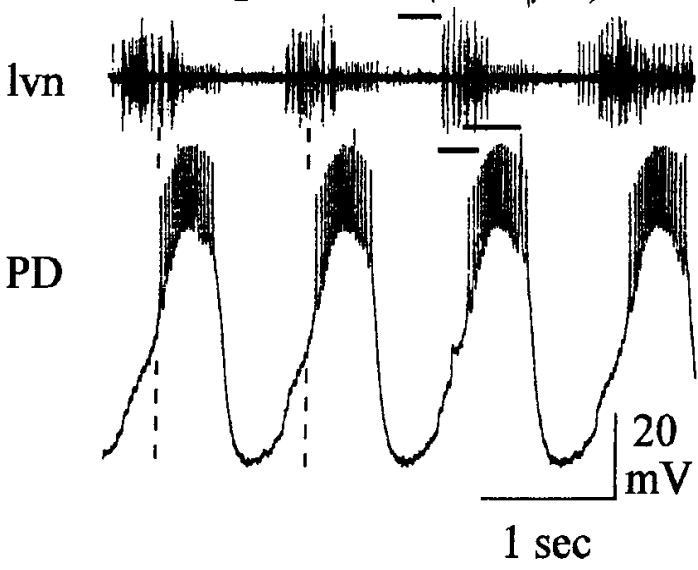

Figure 8. The pyloric network loses its $\mathrm{O}_{2}$ sensitivity after experimental deletion of the LP neuron. $A$, The pyloric rhythm is monitored extracellularly $(l v n)$ in an intact pyloric network at $\mathrm{PU}_{2}=20 \mathrm{kPa}$. Under these conditions, the pyloric network generates ongoing rhythmic activity involving LP (largest spikes), PY (middle spikes), and PD (smallest spikes) neurons. $B$ l, After photoinactivation of $\mathrm{LP}$ and with $\mathrm{PO}_{2}=20 \mathrm{kPa}$, the pyloric network continues to generate spontaneous rhythmic output in which the PY neurons ( $l v n)$ burst in alternation with the PD neurons (recorded intracellularly and $l \mathrm{vn}$ ). B2, A 60 min exposure period with saline at $\mathrm{PO}_{2}=1 \mathrm{kPa}$ has no effect on the pyloric cycle period of the I.P-deleted network. All records were from the same preparation.

to estimate but is several times higher in nervous tissue than elsewhere (for review, see Siesjo, 1978). For example, in resting nerve of crab, the $\mathrm{O}_{2}$ consumption that reflects this energy expenditure has been estimated to be $\approx 70 \mu \mathrm{mol} \cdot \mathrm{min}^{-1} \cdot \mathrm{kg}^{-1}$ (Treherne, 1966). In contrast, the mean value for all tissues, as measured in intact resting crustaceans, is only 15-20 $\mu \mathrm{mol} \cdot \min ^{-1} \cdot \mathrm{kg}^{-1}$ (Forgue et al., 1992b). In the mammalian brain, it is estimated that $>50 \%$ of the energy released is used just for active $\mathrm{Na}-\mathrm{K}$ transport (Clausen et al., 1991). Similar figures were proposed in a crustacean preparation: Giacobini (1965) showed that ouabain induced a $40 \%$ decrease in $\mathrm{O}_{2}$ consumption in an isolated crayfish stretch receptor. Surprisingly, despite this important specific $\mathrm{O}_{2}$ requirement, it is remarkable that in all the crustaceans that we studied (as well as in some fishes and molluscs, i.e., in the three main groups of water breathers; Forgue et al., 1992b), the arterial $\mathrm{PO}_{2}$ in unfed animals at rest is regulated in the $1-3 \mathrm{kPa}$ range, as illustrated in Figure $1 B$ for $H$. gammarus. This corresponds to an apparent set-point, which is maintained regardless of $\mathrm{PO}_{2}$ in the inspired water in the 3-40 kPa range (Massabuau and Burtin, 1984; Forgue et al., 1989; Massabuau et al., 1991). In many physiologically different water breathers, this constancy of the $\mathrm{O}_{2}$ status in the milieu interieur in the low range appears as a characteristic property of gas-exchange regulation.

In vivo, under unfed conditions, i.c., at low artcrial $\mathrm{PO}_{2}$, the pylorus is not as rapidly cycling as it is in postprandial conditions (Rezer and Moulins, 1983). In vitro, we found that superfusion at this low arterial $\mathrm{PO}_{2}$ level slows down the rapidly cycling pyloric rhythm observed at $20 \mathrm{kPa}$ (Figs. 3, 4A,C). Therefore, we propose that the mechanism of $\mathrm{O}_{2}$ action that we report here is a way to reduce energy expenditure when a high level of neuronal activity is not required. In vivo, we are currently studying the blood gas changes that occur after a meal of lobster and their role in the postprandial, increased pyloric frequency.

\section{Comparison with previous data}

Our results do not deal with pathological events and therefore must be distinguished from studies of cerebral hypoxia (Siesjo, 1978; Choi, 1990). Indeed, we observed in H. gammarus that bathing the STG with exceptionally low $\mathrm{PO}_{2}$, between 0 and $1 \mathrm{kPa}$, had significantly different effects from those shown herc. Briefly, in the presence of these exceptionally low $\mathrm{PO}_{2}$ levels, large changes in the global pattern of pyloric activity started within the first hour. The activity pattern then became disrupted, and the membrane potentials of the pyloric network neurons became lightly depolarized (Massabuau and Meyrand, unpublished observations). Finally, it is important to recall that in the present experiments we never observed rapid changes in membrane potential and/or increases in firing frequency, as is usually seen in preparations exposed briefly to anoxic conditions (Leblond and Krnjevic, 1989).

Although the presence of a physiological, nonlethal, and reversible $\mathrm{O}_{2}$ effect on a neuronal network seems original, the idea that tissues in situ could be $\mathrm{O}_{2}$-limited, i.e., in a state of permanent "slight hypoxia," has been proposed previously for various mammalian cell types (Rosenthal et al., 1976; Siesjo, 1978; Rennie, 1983; Chinet and Mejsnar, 1989). Moreover, regarding the brain tissue, some authors suggested that it could work in situ on the verge of $\mathrm{O}_{2}$ insufficiency (Davies and Bronk, 1957; Rosenthal et al., 1976). Indeed, as stressed earlier, in every organ that was studied, most tissue $\mathrm{PO}_{2} \mathrm{~s}$ are in the low range, whereas this is (1) very close to, or even below, $K_{\mathrm{m}} \mathrm{O}_{2}$ for many $\mathrm{O}_{2}$-dependent reactions (Vanderkooi et al., 1991) and (2) just above the critical $\mathrm{PO}_{2}$ below which $\mathrm{O}_{2}$ consumption falls in isolated mitochondria (Chance, 1957; Jobsis, 1972). To our knowledge, however, we have presented here the first study demonstrating that physiological levels of $\mathrm{O}_{2}$ can modulate neural network activity.

\section{Conclusion}

Present data demonstrate that the physiological $\mathrm{PO}_{2}$ occurring at the cellular level can induce fundamental functional changes in neural network activity. We propose that in resting $H$. gammarus, 
A

Figure 9, Characterization of the $\mathrm{O}_{2}$ effect on the pyloric network after experimental deletion of the LP neuron. $A$, Distribution of pyloric cycle periods at $\mathrm{PO}_{2}=20 \mathrm{kPa}($ top $)$, after $60 \mathrm{~min}$ at $\mathrm{PO}_{2}=$ $1 \mathrm{kPa}$ (middle), and after $60 \mathrm{~min}$ recovery at $\mathrm{PO}_{2}=20 \mathrm{kPa}$ (bottom) $(n=30$ cycles preparation; $n=4$ preparations). $B$, Normalized phase relationship of the remaining pyloric neurons at the same $\mathrm{PO}_{2}$ levels as in 4 . Mean $\pm \mathrm{SE}$ ( $n=4$ preparations). Compare Figure $9 A$ with Figure $4 A$, and Figure $9 B$ with Figure 5 .

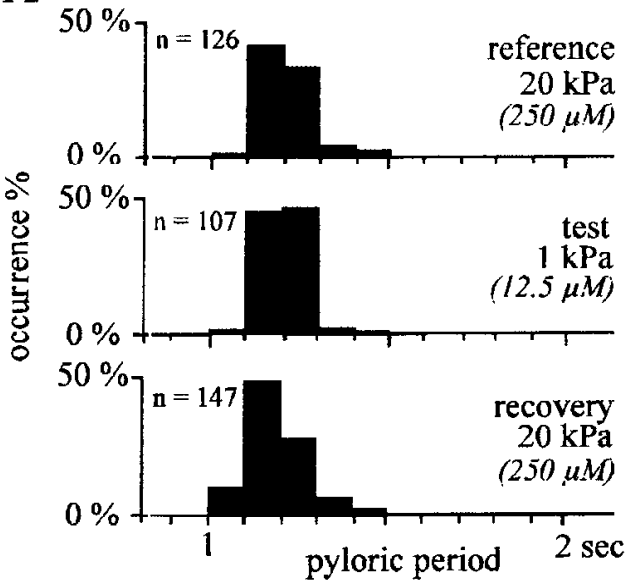

$\mathrm{B}$

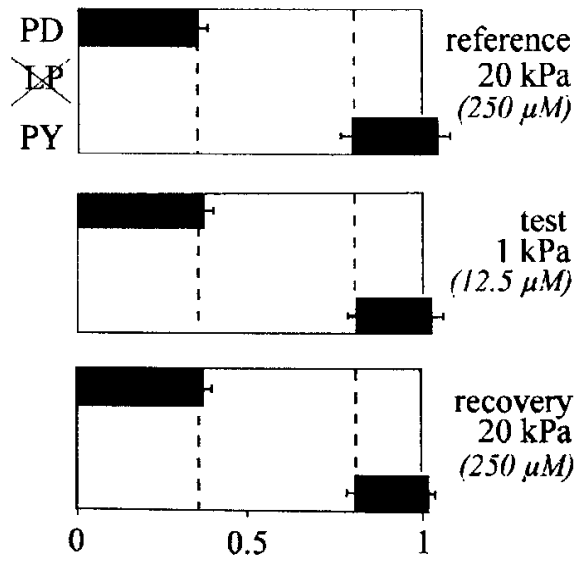

by increasing the pyloric rhythm cycle period, the LP neuron forces the network to slow down, to function at a lower energy cost, and to be less sensitive to a limitation in the $\mathrm{O}_{2}$ supply. Such a mechanism could be a key adaptation for tolerating hypoxia in sensitive neural networks that are operating in poorly oxygenated environments.

\section{REFERENCES}

Bal T, Nagy F, Moulins M (1988) The pyloric central pattern generator in crustacea: a set of conditional neuronal oscillators. J Comp Physiol $163: 715-727$.

Cazalets JR, Cournil I, Geffard M, Moulins M (1987) Suppression of oscillatory activity in crustacean pyloric neurons: implication of

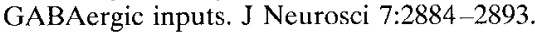

Cazalets JR, Nagy F, Moulins M (1990a) Suppressive control of the crustacean pyloric network by an identified neuron. I. Modulation of the motor pattern. J Neurosci 10:448-457.

Cazalets JR, Nagy F, Moulins M (1990b) Suppressive control of the crustacean pyloric network by an identified neuron. II. Modulation of neuronal properties. J Neurosci 10:458-468.

Chance B (1957) Cellular oxygen requirements. Fed Proc 16:671-680.

Chinet AE, Mejsnar J (1989) Is resting muscle oxygen uptake controlled by oxygen availability? J Appl Physiol 66:253-260.

Choi DW (1990) Cerebral hypoxia: some new approaches and unanswered questions. J Neurosci 10:2493-2501.

Clausen T, Van Hardeveld C, Everts ME (1991) Significance of cation transport in control of energy metabolism and thermogenesis. Physiol Rev 71:733-774.

Connett RJ, Honig CR, Gayeski TEJ, Brooks GA (1990) Defining hypoxia: a systems view of $\mathrm{VO}_{2}$, glycolysis, energetics, and intracellular $\mathrm{PO}_{2}$. J Appl Physiol 68:833-842.

Cournil I, Meyrand P, Moulins M (1990) Identification of all GABAimmunoreactive neurons projecting to the lobster stomatogastric ganglion. J Neurocytol 19:478-493.

Davies PW, Bronk DW (1957) Oxygen tension in mammalian brain. Fed Proc 16:689-692.

Eisen JS, Marder E (1984) A mechanism for the production of phase shifts in a pattern generator. J Neurophysiol 51:1374-1393.

Flamm RE, Harris-Warrick RM (1986a) Aminergic modulation in the lobster stomatogastric ganglion. I. Effects on the motor pattern and activity of neurons within the pyloric circuit. $\mathbf{J}$ Neurophysiol 55:847-865.

Flamm RE, Harris-Warrick RM (1986b) Aminergic modulation in the lobster stomatogastric ganglion. II. Target neurons of dopamine, octopamine and serotonin within the pyloric circuit. $J$ Neurophysiol 55:866-881

Forgue J, Burtin B, Massabuau J-C (1989) Maintenance of oxygen consumption in resting Silurus glanis at ditferent levels of ambient oxygenation. J Exp Biol 143:305-319.

Forgue J, Massabuau J-C, Truchot JP (1992a) When are resting waterbreathers lacking $\mathrm{O}_{2}$ ? Arterial $\mathrm{Po}_{2}$ at the anaerobic threshold in crab. Respir Physiol 88:247-264.
Forgue J, Truchot JP, Massabuau J-C (1992b) Low arterial $\mathrm{Po}_{2}$ in resting crustaceans is independent of blood $\mathrm{O}_{2}$ affinity $\mathrm{J}$ Exp Biol 170:257-264.

Giacobini E (1965) Neurophysiological and biochemical correlations in isolated nerve cell preparations at rest and during activity. In: Drugs and enzymes (Procecdings of the 2nd International Congress of Pharmacology), pp 55-63. Oxford: Pergamon.

Graubard K, Raper JA, Hartline DK (1983) Graded synaptic transmission between identified spiking neurons. J Neurophysiol 50:508-521.

Harris-Warrick RM, Marder M, Selverston AI, Moulins M (1992) Dynamic biological networks: the stomatogastric nervous system. Boston: MIT.

Hartline DK, Gassie DV (1979) Pattern generation in the lobster (Panulirus) stomatogastric ganglion. I. Pyloric neuron kinetics and synaptic interactions. Biol Cybern 33:209-222.

I Iooper SL, Marder E (1987) Modulation of the lobster pyloric rhythm by the peptide proctolin. J Neurosci 7:2097-2112.

Jobsis FF (1972) Oxydative metabolism at low $\mathrm{PO}_{2}$. Fed Proc 31:1404-1413.

Jones DP, Kennedy FG, Andersson BS, Aw TY, Wilson E (1985) When is a mammalian cell hypoxic? Insights from studies of cells versus mitochondria. Mol Physiol 8:473-482.

King D (1976) Organization of crustacean neuropil. I. Patterns of synaptic connections in lobster stomatogastric ganglion. J Neurocytol 5:207-237.

Leblond J, Krnjevic K (1989) Hypoxic changes in hippocampal neurons. J Neurophysiol 62:1-14.

Lubbers DW (1968) The oxygen pressure field of the brain and its significance for the normal and critical oxygen supply of the brain. In: Oxygen transport in blood and tissue (Lubbers DW, Luft UC, Thews G, Witzleb E, eds), pp 124-139. Stuttgart: Georg Thieme.

Massabuau J-C, Burtin B (1984) Regulation of oxygen consumption in the crayfish Astacus leptodactylus at different levels of oxygenation: role of peripheral $\mathrm{O}_{2}$ chemoreception. J Comp Physiol [B] 155:43-49.

Massabuau J-C, Burtin B, Wheatly $M$ (1991) How is $\mathrm{O}_{2}$ consumption maintained independent of ambient oxygen in mussel Anodonta cygnea? Respir Physiol 83:103-114.

Maynard DM (1972) Simpler networks. Ann NY Acad Sci 193:59-72.

Maynard DM, Dando MR (1974) The structure of the stomatogastric neuromuscular system in Callinectes sapidus, Homarus americanus and Panulirus argus. Philos Trans R Soc London [Biol] 268:161-220.

Meyrand P, Simmers A.J, Moulins M (1991) Construction of a pattern generating circuit with neurons of different networks. Nature 351:60-63.

Meyrand P, Simmers AJ, Moulins M (1994) Dynamic construction of a neural network from multiple pattern generators in the lobster stomatogastric nervous system. J Neurosci 14:630-644.

Miller JP (1987) Pyloric mechanisms. In: The crustracean stomatogastric system (Selverston AI, Moulins M, eds), pp 109-145. New York: Springer.

Miller JP, Selverston AI (1979) Rapid killing of single neurons by irradiation of intracellularly injected dye. Science 206:702-704. 
Nagy F, Dickinson PS (1983) Control of a central pattern generator by an identified modulatory interneurone in crustacea. I. Modulation of the pyloric motor output. J Exp Biol 105:33-58.

Nagy F, Dickinson PS, Moulins M (1988) Control by an identified modulatory neuron of the sequential expression of plateau properties and synaptic inputs to a neuron in a central pattern generator. $\mathbf{J}$ Neurosci 8:2875-2886.

Nusbaum MP, Marder E (1989) A modulatory proctolin-containing neuron (MPN). I. Identification and characterization. J Neurosci 9:1591-1599.

Rahn H (1966) Aquatic gas exchange: theory. Respir Physiol 1:1-12.

Rennie MJ (1983) How can oxygen availability affect metabolism and how does it affect sugar transport? In: Hypoxia, exercise, and altitude: Proceedings of the Third Banff International Hypoxia Symposium, pp 289-296. New York: Alan R Liss Inc.

Rezer E, Moulins M (1983) Expression of the crustacean pyloric pattern generator in the intact animal. J Comp Physiol [A] 153:17-28.
Rosenthal M, Lamanna JC, Jobsis FF, Levasseur JE, Kontos HA, Patterson JL (1976) Effects of respiratory gases on cytochrome A in intact cerebral cortex: is there a critical $\mathrm{Po}_{2}$ ? Brain Res 108:143-154.

Selverston AI, Moulins M (1987) The crustracean stomatogastric system. New York: Springer.

Siesjo BK (1978) Brain energy metabolism. New York: Wiley.

Treherne JE (1966) The neurochemistry of arthropods. Cambridge: Cambridgc UP.

Turrigiano GG, Selverston AI (1989) Cholecystokinin-like peptide is a modulator of a crustacean central pattern generator. J Neurosci 9:2486-2501.

Vanderkooi JM, Erecinska M, Silver IA (1991) Oxygen in mammalian tissue: methods of measurement and affinities of various reactions. Am J Physiol 260:C1131-C1150.

Wegener G (1981) Comparative aspects of energy metabolism in nonmammalian brains under normoxic and hypoxic conditions. In: Animal models and hypoxia (Stefanovitch V, ed), pp 87-107. Oxford: Pergamon. 